\title{
ARTIKEL
}

\section{Metatoezicht op voedselveiligheid}

\author{
Paul Verbruggen \& Tetty Havinga
}

\section{$1 \quad$ Inleiding}

Toezicht op voedselveiligheid is een aangelegenheid van zowel publieke als private partijen. Overheid en bedrijfsleven dragen beide verantwoordelijkheid voor controle en naleving van voedselveiligheidsnormen. Zij hebben daartoe allebei geavanceerde systemen van toezicht ontwikkeld met als primair doel risico's op het gebied van voedselveiligheid te beheersen en beperken. Kenmerkend is de relatief recente ontwikkeling dat publieke en private actoren elkaars inspanningen voor de verwezenlijking van dit doel onderling pogen af te stemmen. Coördinatie tussen deze partijen kent een grote diversiteit en spreekt tot de verbeelding in tijden van globalisering van voedselketens, internationalisering van publiek toezicht en nationale bezuinigingen. ${ }^{1}$ Onduidelijk is echter nog in hoeverre een dergelijke 'hybridisatie' van toezicht bijdraagt aan een betere controle op voedselveiligheid. Verschillende risico's lijken nadrukkelijk aanwezig, voornamelijk die met betrekking tot 'regulatory capture', transparantie en verantwoording. ${ }^{2}$

De vraag rijst op welke wijze tegenwicht aan deze risico's kan worden geboden. Een publieke toezichthouder zal zich nimmer willen verlaten op privaat toezicht zonder zich te vergewissen van de naleving van dwingendrechtelijke voorschriften en de waarborging van hetzelfde (zo niet hogere) beschermingsniveau. In Nederland probeert de Nederlandse Voedsel- en Warenautoriteit (NVWA) toezicht te houden op private vormen van toezicht. Hoe richt de NVWA dit metatoezicht (toezicht op toezicht) in? Welke waarborgen pleegt de NVWA aan te brengen bij de afstemming van haar toezicht op private initiatieven en op welke punten behoeft dit verbetering?

Deze vragen zijn pertinent nu de NVWA door opeenvolgende bezuinigingsrondes gedwongen wordt tot verdergaande afstemming met private toezichthouders. Ook elders worden publieke toezichthouders met dezelfde beleidskeuzes geconfronteerd. Zo is sinds 2011 de standaardinspectiefrequentie van melkveehouderijen die deelnemen aan de Assured Dairy Farm scheme in Engeland en Wales

1 T. Havinga \& F. van Waarden, Veilig voedsel: Toezicht toevertrouwen? Sectorschets toezicht in de voedselsector, Den Haag: Wetenschappelijke Raad voor het Regeringsbeleid 2013 (Webpublicatie nr. 70).

2 M. Garcia Martinez, P. Verbruggen \& A. Fearne, Risk-based Approaches to Food Safety Regulation: What Role for Co-regulation?, Journal of Risk Research 2013-9, p. 1101-1121. 
teruggebracht van eenmaal per twee jaar naar eenmaal per tien jaar. ${ }^{3}$ De Canadian Food Inspection Agency kondigde onlangs aan richtlijnen te willen ontwikkelen voor de erkenning van third-party service delivery providers. ${ }^{4}$ De U.S. Food \& Drug Administration wil bij de implementatie van de nieuwe Food Safety Modernization Act gebruik maken van certificering door erkende geaccrediteerde third-party auditors bij de controle op de import van voedsel..$^{5}$ In Nederland doen zich ook op andere beleidsterreinen vergelijkbare discussies voor over de relatie tussen publiek en privaat toezicht, zoals bijvoorbeeld het bouw- en woningtoezicht, ${ }^{6}$ audiovisuele media ${ }^{7}$ en toezicht op consumentenbescherming. ${ }^{8}$

De gestelde onderzoeksvragen staan centraal in een verkennend onderzoek waarin we een vergelijkende analyse maken van twee initiatieven van privaat toezicht, te weten Bureau de Wit en Riskplaza. Deze initiatieven zijn beide door de NVWA geaccepteerd als 'zelfcontrolesysteem' voor levensmiddelen. De keuze voor Bureau de Wit en RiskPlaza wordt in paragraaf 5 nader toegelicht. Wat eerst volgt, is een uiteenzetting van het concept metatoezicht (2), factoren die hebben bijgedragen aan de ontwikkeling van publiek toezicht op private voedselveiligheidcontrole (3) en de verschillende vormen van metatoezicht (4). Vervolgens wordt inzicht gegeven in de door ons gevolgde methodologie (5). De analyse van Bureau de Wit (6) en RiskPlaza (7) richt zich op het systeem van privaat toezicht en de wijze waarop de NVWA haar toezicht daaraan koppelt. Deze resultaten worden vervolgens vergeleken en bediscussieerd teneinde het verschil in metatoezicht te duiden en de daaraan verbonden risico's uiteen te zetten (8).

3 Food Standards Agency, Outcome of the Public Consultation on proposals to amend the frequency of certain official control inspections for on farm dairy hygiene in England \& Wales, 2011, <www.food.gov.uk/multimedia/pdfs/consultationresponse/consummdairyhygienecon trol.pdf> (30 augustus 2013).

4 Canadian Food Inspection Agency, Improved Food Inspection Model. Proposed Draft, 2012, <www.inspection.gc.ca/DAM/DAM-aboutcfia-sujetacia/STAGING/text-texte/acco_moderniza tion_modeldraft_1344008567583_eng.pdf> (30 augustus 2013).

5 U.S. Food \& Drug Administration, FSMA Facts. Proposed Rule on Accreditation of Third-Party Auditors, 2013, <www.fda.gov/downloads/Food/GuidanceRegulation/FSMA/UCM362561.pdf> (8 januari 2014).

6 Vereniging Bouw- \& Woningtoezicht Nederland, Privaat wat moet, publiek wat onvermijdelijk is. Voorlopig visiedocument kwaliteitsborging, versie 12 maart 2013, <www.bwtinfo.nl/upload/ ckfinder/files/Duaal/ PRIVAAT\%20WAT\%20MOET120313.pdf> (30 augustus 2013).

7 B.R. Dorbeck-Jung e.a., Contested Hybridization of Regulation: Failure of the Dutch Regulatory System to Protect Minors from Harmful Media, Regulation \& Governance 2010-1, p. 154-174.

8 Op grond van art. 5.1 lid 3 en 6.1 lid 2 jo. lid 3 van de Wet handhaving consumentenbescherming, zoals onlangs gewijzigd door art. 30 van de Instellingswet Autoriteit Consument en Markt (ACM), Stb. 2013, 102, kan ACM haar toezicht afstemmen met andere relevante spelers in het veld door zogenoemde samenwerkingsprotocollen te sluiten. De protocollen die ACM heeft opgesteld met private toezichthouders betreffen de Consumentenbond, Stichting Geschillencommissies Consumentenzaken en Stichting Reclame Code. ACM, Nationale Samenwerking, <www.acm.nl/nl/organisatie/samenwerking/samenwerking-nationaal/> (30 augustus 2013). 


\section{Metatoezicht?}

Wat bedoelen we met het concept 'metatoezicht'? Metatoezicht is kort gezegd toezicht op toezicht. Binnen een systeem van metatoezicht is een toezichthouder die naleving van regelgeving door onder toezicht gestelden toetst ook zelf aan toezicht onderhevig. De partij die dit 'tweedelijnstoezicht' verzorgt, houdt in beginsel zelf geen toezicht op de onder toezicht gestelden. ${ }^{9}$ Haar rol is beperkt tot controle, sturing en vormgeving van het eerstelijnstoezicht dat wordt uitgeoefend door een andere partij zoals een certificatie-instelling, visitatiecommissie of accreditatieorgaan. Metatoezicht impliceert als het ware dus een tweetrapsraket van de vormgeving en uitvoering van toezicht. ${ }^{10}$

Metatoezicht onderscheidt zich van systeemtoezicht. Systeemtoezicht kenmerkt zich door controle op bedrijfsniveau en de manier waarop een individueel bedrijf door middel van veiligheidssystemen of vergelijkbare interne complianceprogramma's de naleving van regels borgt en risico's beheerst. ${ }^{11}$ Metatoezicht richt zich daarentegen op het toezicht dat een externe partij op een bedrijf houdt. Metatoezicht kan echter wel systeemtoezicht omvatten. Dat is het geval indien de externe toezichthouder (bijvoorbeeld een certificatie-instelling) toetst of het risicobeheersingssysteem van een bedrijf voldoet aan de geldende regelgeving, terwijl zij ook zelf aan controle en inspectie onderhevig is (in de vorm van accreditatie bijvoorbeeld). Metatoezicht ziet dan op de relatie tussen het eerstelijns- en tweedelijnstoezicht en niet, zoals bij systeemtoezicht, op de beheerssystemen op bedrijfsniveau. Daarmee onderscheidt metatoezicht zich ook van het door De Ridder omschreven 'proxy-toezicht'. ${ }^{12}$ Deze vorm van toezicht betreft de situatie 'dat een bestuursorgaan binnen de organisatie in het bijzonder wordt belast met de behartiging van het belang dat de toezichthouder voorstaat'. ${ }^{13}$ Als gevolg hiervan verschuift dus een deel van de toezichttaak van de overheidstoezichthouder naar een onder toezicht gesteld bedrijf en wordt een beroep gedaan op het zelfregulerend vermogen van het bedrijf om (beter) toezicht te houden.

Metatoezicht omvat derhalve activiteiten van toezichthouders die erop gericht zijn mechanismen, procedures en instrumenten van controle en inspectie van andere toezichthouders te reguleren en te sturen. Het kunnen uitoefenen van een dergelijke invloed veronderstelt een bepaalde mate van autoriteit en controle,

9 A. Nagelkerke, M. Kneppers \& L. Meijer, Verkenning vermindering controledruk door tweedelijns toezicht, Den Haag: Schuttelaar en partners 2009.

10 Anders: F. Mertens, Inspecteren. Toezicht door inspecties, Den Haag: Sdu Uitgevers 2011, p. 171. Mertens bepleit een beperking van de term 'tweedelijnstoezicht' tot situaties waarin het toezicht wordt overgedragen van de ene aan een andere (meer gespecialiseerde) instantie, naar analogie van het onderscheid tussen huisarts en medisch specialist in de gezondheidszorg.

11 Zie uitgebreid: J.K. Helderman \& M. Honingh, Systeemtoezicht. Een onderzoek naar de condities en werking van systeemtoezicht in zes sectoren, Den Haag: Boom Juridische uitgevers 2009 en M.A. de Bree, Hoe landelijke inspectiediensten omgaan met systeemtoezicht, TvT 2010, nr. 3, p. 51-70. In de Anglo-Amerikaanse literatuur worden vaak de begrippen 'enforced self-regulation' en 'management-based regulation' gebruikt. Zie voor een overzicht: S. Gilad, It runs in the family: Meta-regulation and its siblings, Regulation \& Governance 2010-4, p. 485-506.

12 J. de Ridder, Proxy-toezicht, TvT 2013, nr. 1, p. 23-40.

13 J. de Ridder, Proxy-toezicht, TvT 2013, nr. 1, p. 26. 
maar niet per definitie een strikt juridische. Metatoezicht sluit daarmee nauw aan bij het concept van 'metaregulering'. Hoewel Coglianese en Mendelson terecht opmerken dat er in de literatuur geen overeenstemming bestaat over wat metaregulering is, ${ }^{14}$ beschrijft Parker de kern treffend als 'regulating the regulators, whether they be public agencies, private corporate self-regulators or third party gatekeepers'. ${ }^{15}$ Onder metaregulering verandert de rol van de regulerende instantie - in de woorden van Osborne en Gaebler - van rowing naar steering. ${ }^{16}$ In plaats van zelfstandig regels te stellen, te monitoren en te handhaven, vindt er regulering op afstand plaats, waarbij de metareguleerder zich verlaat op de mechanismen van anderen, maar corrigerend optreedt indien deze niet toereikend worden geacht.

Verschillende partijen (zowel publieke als private) kunnen metaregulerend optreden door invloed uit te oefenen op en voorwaarden te stellen aan de reguleringsactiviteiten van anderen, of het nu de normering, implementatie, toezicht of handhaving betreft. ${ }^{17}$ Zo bezien is metatoezicht een vorm van metaregulering welke is toegesneden op de activiteit van toezicht binnen een reguleringssyteem. Ofschoon de analyse in deze bijdrage zich zal toespitsen op twee private initiatieven voor toezicht ten aanzien waarvan de NVWA metatoezicht uitoefent, omvat metaregulering en -toezicht in onze visie niet enkel de beïnvloeding van private mechanismen door publieke actoren, maar ook het toezicht van private partijen op publieke instanties, alsmede van private en publieke partijen onderling. ${ }^{18}$ Ten slotte merken we op dat de conceptualisering van het begrip metatoezicht als een vorm van metaregulering niet betekent dat de regelgeving waarop wordt toegezien, metaregulerend van aard moet zijn, hoewel dat niet per definitie is uitgesloten.

\section{Drivers voor metatoezicht}

Welke factoren hebben bijgedragen aan de ontwikkeling van publiekrechtelijk toezicht op private controles op het beleidsterrein van voedselveiligheid? Ten eerste speelt het feit dat de capaciteit van publiekrechtelijke toezichthouders om voedselveiligheid te garanderen in toenemende mate onder druk is komen te

14 C. Coglianese \& E. Mendelson, Meta-regulation and Self-regulation, in: M. Cave, R. Baldwin \& M. Lodge (red.), The Oxford Handbook of Regulation, Oxford: Oxford University Press 2010, p. 147.

15 C. Parker, The Open Corporation: Effective Self-regulation and Democracy, Cambridge: Cambridge University Press 2002, p. 15. Zie voor een bredere discussie over de definitie van metaregulering: R. Baldwin, M. Cave \& M. Lodge, Understanding Regulation: Theory, Strategy, and Practice (2nd ed.), Oxford: Oxford University Press 2011, p. 137-164.

16 D. Osborne \& T. Gaebler, Reinventing Government: How the Entrepreneurial Spirit is Transforming the Public Sector, Reading, MA: Addison-Wesley 1992.

17 C. Scott, Regulating everything: From mega- to meta-regulation, Administration 2012-1, p. 61-89. Scott gebruikt het concept 'regulatory regime' om te benadrukken dat verschillende private en publieke partijen op verschillende manieren een bijdrage leveren aan regulering en de controle daarvan (p. 65 e.v.).

18 Zie par. 3 infra. Zie uitgebreid: P. Verbruggen \& T. Havinga, The Meta-Regulatory Turn in Transnational Private Regulation (te verschijnen). 
staan. Dit kent verschillende oorzaken. Twee van de meest kenmerkende worden hier kort behandeld, namelijk de globalisering van handelsketens in voedselproducten en aanhoudende reorganisaties en bezuinigingen bij de NVWA. De productie van voedingsmiddelen wordt vandaag de dag gekenmerkt door ketens die internationaal zijn. Dat betekent dat de verschillende stadia van productie niet binnen de jurisdictie van één en dezelfde nationale publieke toezichthouder liggen. Dit maakt het voor nationale overheidstoezichthouders moeilijk om de kwaliteit en veiligheid van het gehele productieproces te garanderen. In Nederland is dit probleem van groot belang nu ons land een vooraanstaande rol inneemt in de wereldvoedselhandel. Wat betreft groenten is Nederland goed voor $12 \%$ van de totale wereldhandel, maar ook in andere categorieën producten is het aandeel van Nederland in de wereldhandel groot. ${ }^{19} \mathrm{Om}$ deze positie te behouden heeft Nederland er belang bij om de veiligheid van het verhandelde voedsel te waarborgen, maar dit stelt de NVWA voor een schier onmogelijke taak. Vandaar dat haar toezicht steeds meer verweven raakt met dat van andere toezichthouders, zowel publiek als privaat, alsmede nationaal en internationaal.

Daartegenover staat dat de NVWA de afgelopen jaren geconfronteerd is met aanhoudende rondes van reorganisatie en bezuinigingen. ${ }^{20} \mathrm{Als}$ gevolg hiervan worden minder vaak periodieke nalevingscontroles uitgevoerd. Ingezet wordt op efficiency. De NVWA hoopt dat onder meer te bewerkstelligen door zogenoemd 'systeemtoezicht' na te streven. ${ }^{21}$ Dit houdt zoveel in als een verschuiving van toezicht op prescriptieve normen naar toezicht op productieprocessen en door bedrijven aangewende HACCP-systemen. ${ }^{22}$ Hoewel het maar de vraag is in hoeverre deze aanpak zal leiden tot kostenbesparing, ${ }^{23}$ past binnen deze benadering ook een hechtere samenwerking met private initiatieven voor toezicht. Afstemming met deze initiatieven kan immers gaten opvullen die vallen in het net van overheidstoezicht, zo is de gedachte. Of andersom geformuleerd: overheidstoezicht kan worden verminderd wanneer het bedrijfsleven zelf zorgt voor adequate controles. Zo kan de toezichtlast voor bedrijven veroorzaakt door publieke toezichthouders worden verminderd.

19 UN International Merchandise Trade Statistics 2011, Vegetables, fresh, chilled, frozen, simply preserved; roots 054, <http://comtrade.un.org/pb/FileFetch.aspx?docID=4527\&type=commod itypagesnew> (30 augustus 2013).

20 Zie in detail: Havinga \& Van Waarden 2013, par. 4.2. Naar aanleiding van diverse incidenten werd in december 2013 een uitbreiding van het aantal voedselinspecteurs aangekondigd (brief van de staatssecretaris van Economische Zaken en de minister van Volksgezondheid, Welzijn en Sport aan de Tweede Kamer d.d. 19 december 2013, Plan van aanpak NVWA).

21 Helderman \& Honingh 2009.

22 HACCP staat voor Hazard Analysis and Critical Control Points en is een methode om veiligheidsrisico's in het productieproces van voedsel te identificeren, te evalueren en te beheersen. HACCP werd in de jaren zestig ontwikkeld voor NASA om uit te sluiten dat voedsel en drinken voor astronauten verontreinigd zou zijn met pathogenen, giftige stoffen of vreemde stoffen. De methode is daarna opgenomen in geldende wetgeving en opgelegd aan bedrijven als verplichte wijze van beheersing van risico's voor voedselveiligheid. Zie voor Nederland art. 2 lid 1 Warenwetbesluit hygiëne van levensmiddelen.

23 Helderman \& Honingh 2009 en C. Maas, Toezicht en zelfregulering herijkt. Vooronderzoek naar 'kansen en bedreigingen' van terugtredend toezicht, Utrecht: Nederlandse Voedsel- en Warenautoriteit 2011. 
Een tweede factor die een beslissende rol speelt bij de ontwikkeling van metatoezicht is het veranderende wetgevingskader. Als reactie op de BSE-crisis in 1996 zijn zowel op nationaal als Europees niveau vergaande hervormingen wat betreft de structuur van toezicht en handhaving van voedselveiligheidsnormen doorgevoerd. ${ }^{24}$ Waar voedselveiligheid voorheen in de eerste plaats werd gezien als overheidstaak, is zij in het huidige Europese bestel een gedeelde verantwoordelijkheid van bedrijfsleven en overheid. Verordening 2002/178/EG - de Verordening inzake Algemene levensmiddelenwetgeving - verplicht levensmiddelenbedrijven en diervoederbedrijven ervoor zorg te dragen dat zij in ieder stadium van de productie, verwerking en distributie voldoen aan de toepasselijk wettelijke voorschriften. De lidstaten moeten een effectief systeem van toezicht en handhaving onderhouden om daarop toe te zien. ${ }^{25}$ Door de verantwoordelijkheid voor voedselveiligheid en controle tevens bij het bedrijfsleven te leggen, werd het voor publieke toezichthouders mogelijk om taken en middelen te herzien en te herverdelen.

Andere Europese regelgeving die ziet op de invulling van de toezichttaken van de overheid werkt deze heroriëntatie verder in de hand. Zo vergt Verordening 2004/882/EG dat de NVWA regelmatig en op basis van een risicobeoordeling inspecties uitvoert rekening houdende met de vastgestelde risico's, antecedenten van bedrijven, betrouwbaarheid van die bedrijven en door henzelf uitgevoerde controles en andere informatie die kan duiden op niet-naleving. De preambule van de Verordening maakt duidelijk dat de frequentie van inspectie proportioneel moet zijn aan het risico dat een bedrijf vormt voor voedselveiligheid, daarbij

'rekening houdende met de resultaten van de controles van exploitanten van diervoeder- en levensmiddelenbedrijven in het kader van op HACCPgebaseerde controleprogramma's of programma's voor kwaliteitsborging, voor zover deze bedoeld zijn voor de naleving van de wetgeving inzake diervoeders en levensmiddelen en de voorschriften inzake diergezondheid en dierenwelzijn.'26

Dergelijk risicogericht of -gestuurd toezicht, dat plaatsvindt op het niveau van individuele bedrijven, bedrijfssectoren en voedselketens, kan dus worden aangevuld door middel van private controleprogramma's. Door thans een nauwere samenwerking aan te knopen met instellingen die deze programma's aanbieden, geeft de NVWA uitvoering aan haar wettelijke toezichttaken. Het gevolg is een sterke mate van hybridisatie van toezicht op voedselveiligheid.

24 Zie in detail: E. Vos, EU Food Safety Regulation in the Aftermath of the BSE Crisis, Journal of Consumer Policy 2000-3, p. 227-255.

25 Art. 17 van Verordening 2002178/EG van het Europees Parlement en de Raad van 28 januari 2002 tot vaststelling van de algemene beginselen en voorschriften van de levensmiddelenwetgeving, tot oprichting van een Europese Autoriteit voor voedselveiligheid en tot vaststelling van procedures voor voedselveiligheidsaangelegenheden, PbEG 2002, L 31/1.

26 Verordening 2004/882/EG van het Europees Parlement en de Raad van 29 april 2004 inzake officiële controles op de naleving van de wetgeving inzake diervoeders en levensmiddelen en de voorschriften inzake diergezondheid en dierenwelzijn, PbEG 2004, L 191/1. 
Een derde factor die van belang is voor de opkomst van metatoezicht op het terrein van voedselveiligheid is de druk vanuit het bedrijfsleven. Beheerders van private controlesystemen hebben er belang bij om erkend te worden door de NVWA. Dit belang is aanzienlijk, omdat erkenning door de NVWA als het ware een predicaat van gedegenheid en betrouwbaarheid is dat aangewend kan worden om meer (betalende) klanten te werven. Dat is de primaire motivatie en 'buy in' van private toezichthouders om medewerking te verlenen aan het metatoezicht van de NVWA. Anderzijds biedt deze motivatie grond voor de NVWA om samenwerking aan te knopen met private toezichthouders. Immers, metatoezicht veronderstelt een bepaalde mate van medewerking van de onder toezicht gestelden en is in die zin geen eenrichtingsverkeer. In het bestaan van deze specifieke motivatie schuilt echter ook het risico dat het privaat belang (van klantenwerving en winst) voor het publieke belang (van strenge controle en voedselveiligheid) wordt gesteld. Hier zal de NVWA specifieke waarborgen tegen moeten inbouwen. Niet alleen vanuit de private controlesystemen maar ook vanuit het bedrijfsleven is de wens geuit dat de NVWA rekening zou moeten houden met private voedselveiligheidssystemen en controles. ${ }^{27}$ Een dergelijke wens sluit goed aan bij de regeringsdoelstelling van vermindering van de regeldruk en toezichtlast voor het bedrijfsleven. ${ }^{28}$

\section{Vormen van metatoezicht}

Op het terrein van voedselveiligheid is metatoezicht in verschillende vormen en op verschillende niveaus zichtbaar. Zo is bijvoorbeeld sprake van toezicht door de Food and Veterinary Office van de Europese Unie op het toezicht dat de NVWA houdt op de productie van en handel in levensmiddelen en voedsel. Dit betreft publiek toezicht van een Europese instantie op publiek toezicht door een nationale toezichthouder. Op haar beurt houdt de NVWA ook toezicht op de wijze waarop controle-instanties zoals COKZ en Skal toezicht houden op respectievelijk de zuivelindustrie en de productie en handel van biologisch voedsel. Dit is een vorm van publiek metatoezicht op private organisaties met een wettelijke toegewezen taak. Een voorbeeld van privaat toezicht op privaat toezicht is de erkenning van certificatie-instellingen door brancheorganisaties die voedselveiligheidsstandaarden, zoals GlobalG.A.P., BRC en IFS beheren.

In deze bijdrage richten we ons op een nieuwe vorm van metatoezicht, namelijk het toezicht van de NVWA op zogenoemde 'zelfcontrolesystemen'. De NVWA controleert de manier waarop een externe private organisatie controleert hoe levensmiddelenbedrijven intern hun controle op voedselveiligheid hebben gere-

27 Zo is bijna de helft van de door ISACert gecertificeerde bedrijven van mening dat de NVWA onvoldoende rekening houdt met bestaande auditresultaten en verbeterplannen. <http://nether lands.isacert.com/artikelen/Resultaten\%20enquete\%20betrouwbaarheid\%20certificaten-94. html> (30 augustus 2013).

28 Regeerakkoord VVD-PvdA, Bruggen Slaan, 20 oktober 2012, <www.kabinetsformatie2012.nl/ bestanden/formaties/formatie-2012/documenten/regeerakkoord/20121029-definitief-regeer akkoord.pdf> (30 augustus 2013), p. 10, zoals uitgewerkt in het document Goed Geregeld, een verantwoorde vermindering van regeldruk 2012-2017, directoraat-generaal Bedrijfsleven \& Innovatie, Den Haag 25 april 2013. 
geld. Dit betreft dus publiek toezicht op extern privaat toezicht op intern privaat toezicht. Sinds een aantal jaren moedigt de NVWA bedrijven in de levensmiddelen- en diervoedersector aan om gebruik te maken van eigen controle op de veiligheid van voedsel en diervoeder. De NVWA accepteert eind augustus 2013 elf zogenoemde 'zelfcontrolesystemen' in de levensmiddelensector en vier in de diervoedersector. Volgens de website van de NVWA zijn dit 'private systemen, waar bedrijven min of meer vrijwillig aan deel kunnen nemen, met als reikwijdte (een deel van) de diervoeder- of voedselveiligheid. Deze systemen kenmerken zich door een interne borging en min of meer onafhankelijke beoordeling en een voldoende zelfregulerend en corrigerend vermogen. ${ }^{29}$ De NVWA beoordeelt zelfcontrolesystemen op hun werking en betrouwbaarheid via audits en inspecties. Ze zegt toe rekening te zullen houden met deze geaccepteerde zelfcontrolesystemen door aanpassing van de bezoekfrequentie, diepgang van inspecties, tijdbesteding en interventies bij deelnemende bedrijven.

De tot dusverre geaccepteerde 'zelfcontrolesystemen' betreffen certificatie of controlesystemen van Nederlandse bedrijven of organisaties gericht op Nederlandse levensmiddelenbedrijven. Levensmiddelenbedrijven zijn niet verplicht om deel te nemen aan een dergelijk systeem. Deze controleprogramma's kennen verscheidene vormen. De NVWA maakt onderscheid tussen systemen die zijn gericht op naleving van de hygiënecode in ambachtelijke bedrijven die geen EG-erkenning hebben en andere systemen die zich richten op een bepaalde productieketen, een bepaald aspect van voedselveiligheid of bedrijfsspecifieke voedselveiligheidssystemen. In sommige gevallen gaat het om een initiatief van een brancheorganisatie, zoals bijvoorbeeld de Vereniging van Keurslagers of een productschap (Akkerbouw, Ei). In een ander geval betreft het een bedrijf dat eigen toeleveranciers controleert (ketenkeuring door slachterij Vion). De overige zelfcontrolesystemen betreffen organisaties die tegen betaling controle, advies of certificatiediensten aanbieden. De NVWA heeft wijdverbreide internationale certificatiesystemen voor de borging van voedselveiligheidsrisico's, zoals BRC, IFS, GlobalG.A.P., (nog) niet geaccepteerd. De NVWA richt zich voor nu slechts op nationale systemen, temeer ook omdat zij nog te vaak overtredingen constateert bij bedrijven die overeenkomstig deze internationale standaarden gecertificeerd zijn. ${ }^{30}$ Er zijn thans wel gesprekken over acceptatie van certificatie door (Nederlandse) certificatie-instellingen zoals ISACert. ${ }^{31}$ Eveneens onderzoekt de NVWA of acceptatie mogelijk is van certificatie op basis van een van de voedselveiligheidsstandaarden die zijn erkend door de Global Food Safety Initiative (GFSI).

Naast acceptatie van 'zelfcontrolesystemen' heeft de NVWA ook enkele convenanten afgesloten met bedrijven en verenigingen van bedrijven. De afspraken in deze convenanten lijken veel op de criteria die gelden voor acceptatie van een zelfcontrolesysteem. Twee convenanten betreffen dan ook een zelfcontrolesys-

29 <www.vwa.nl/onderwerpen/meest-bezocht-a-z/dossier/zelfcontrolesystemen-diervoeders-enlevensmiddelen/wat-betekenen-zelfcontrolesytemen-voor-bedrijven> (30 augustus 2013).

30 H. Beuger, Overheidstoezicht en certificatie. Verhogen betrouwbaarheid vergt inspanning van alle betrokkenen, Voedingsmiddelentechnologie 2012-9, p. 20-21.

31 ISACert, ISACert Compliance Module, <www.isacert.com/beeldenbank/File/Netherlands/ISACert \%20Compliance+\%20Module\%20(2).pdf> (30 augustus 2013). 
teem, maar niet alle. Met andere woorden, niet alle partijen waarmee een convenant is gesloten beheren een geaccepteerd zelfcontrolesysteem. Bovendien zijn de gemaakte afspraken bij de meeste zelfcontrolesystemen niet in een convenant vastgelegd. In deze bijdrage beperken we ons tot twee zelfcontrolesystemen die geaccepteerd zijn, ongeacht of zij een convenant hebben gesloten met de NVWA.

\section{Methodologie}

Om nader zicht te krijgen op de wijze waarop de NVWA toezicht houdt op geaccepteerde zelfcontrolesystemen hebben we twee van die systemen nader onderzocht, namelijk Bureau de Wit (BDW) en RiskPlaza. Er is geen sprake van een theoretisch gestuurde selectie. Over de meeste geaccepteerde zelfcontrolesystemen was bij aanvang van ons onderzoek vrijwel geen nadere informatie bekend. Ook over de inhoud van de afspraken met de NVWA was in de meeste gevallen niet meer bekend dan dat de NVWA haar inspectiefrequentie zou aanpassen. Bij de keuze van de twee casus hebben we gestreefd naar variatie. Het systeem van BDW is een van de zeven geaccepteerde systemen die controleren of een aangesloten ambachtelijk bedrijf voldoet aan de toepasselijke hygiënecode; de klanten betreffen bedrijven in horeca, retail, ambacht en zorg. ${ }^{32} \mathrm{BDW}$ is een commercieel bedrijf dat controleert of klanten aan de eisen van de toepasselijke branchehygiënecode voldoen met een eigen keurmerk. De keuze voor Bureau de Wit is toevallig, het was de eerste op de alfabetische lijst. RiskPlaza is een van vier overige zelfcontrolesystemen. ${ }^{33}$ De keuze voor RiskPlaza is mede ingegeven doordat het door vele betrokkenen wordt gezien als een modelvoorbeeld van deze nieuwe vorm van samenwerking. ${ }^{34}$ RiskPlaza is tot stand gekomen op initiatief van het Productschap Akkerbouw en de bakkerijsector en is gericht op de beheersing van gevaren en risico's van grondstoffen en ingrediënten. Riskplaza bestaat enerzijds uit een database van gevaren en risico's en anderzijds uit een daaraan gekoppeld auditsysteem dat wordt uitgevoerd door erkende geaccrediteerde certificatie-instellingen.

BDW en RiskPlaza verschillen op een aantal wezenlijke punten die naar verwachting mede bepalend zullen zijn voor de wijze waarop het metatoezicht door de NVWA wordt ingevuld. In de eerste plaats is BDW B.V. een middelgroot commercieel bedrijf met vijftig jaar ervaring met keuring en certificatie. RiskPlaza is een recent opgezet multi-stakeholder initiatief en heeft geen winstoogmerk. Dit verschil lijkt van belang voor het risico op belangenverstrengeling (regulatory capture) en de NVWA zou daar extra waarborgen voor kunnen inbouwen. Deelname aan het BDW-zelfcontrolesysteem betekent geen controle meer door NVWA, terwijl controle via RiskPlaza-audit+ slechts leidt tot gedeeltelijke vervanging van

32 Dit zijn de zeven commerciële bureaus: Bureau de Wit, Houwers Holtackers, Kroonenburg Advies, Sensz BV en KBBL Inspectie B.V., de Vereniging voor Keurslagers en de Stichting Voedsel Veiligheidsinspectie Wageningen.

33 Het betreft verder Toezicht op controle eiersector (IKB-ei), de ketenkeuring van de VION Food Group en de Stichting Certificatie Voedselveiligheid (Nederlands HACCP-certificaat).

Havinga \& Van Waarden 2013, p. 61. 
NVWA-controles. Dit verschil zou van invloed kunnen zijn op de eisen die de NVWA stelt aan samenwerking. Voorts controleert BDW op basis van reeds bestaande en goedgekeurde branchehygiënecodes; RiskPlaza heeft in haar database de normen met betrekking tot grondstoffen geconcretiseerd met inbreng van de NVWA, sectordeskundigen en de bij RiskPlaza aangesloten certificatieinstellingen. De samenwerking bij RiskPlaza betreft dus niet alleen de controle op naleving maar ook de concretisering van de regels. Het lijkt ons aannemelijk dat dit gevolgen zou kunnen hebben voor het metatoezicht door de NVWA.

Bij de beschrijving van de twee voorbeelden van private zelfcontrolesystemen zullen we nagaan welke organisaties zijn betrokken bij het reguleringsregime. In de literatuur wordt onderscheid gemaakt tussen bedrijven om welker gedrag het gaat (eerste partij), leveranciers en afnemers van dit bedrijf (tweede partij), bedrijven en organisaties die niet rechtstreeks zijn betrokken bij de transacties in de voedselketen zoals geaccrediteerde certificatie-instellingen of consumentenorganisaties (derde partij), en ten slotte overheidsorganisaties (vierde partij). ${ }^{35}$ De voedselketen 'van boerderij tot bord' kent vele actoren die elk in verschillende fasen eerste partij zijn en in andere fasen tweede partij. We veronderstellen dat des te groter de pluriformiteit van de partijen in het reguleringsregime, des te beter de verschillende belangen elkaar in evenwicht zullen houden. Hierdoor wordt het risico kleiner dat de toezichthouder wordt ingekapseld en dat één privaat belang allesbepalend is.

We gaan tevens na welke wederzijdse verplichtingen er zijn tussen een deelnemend bedrijf, het zelfcontrolesysteem, de NVWA en eventuele andere partijen en wat de juridische vorm van deze verplichtingen is. De controlesystematiek van de systemen wordt eveneens beschreven (frequentie en aard van inspecties).

Nadat het zelfcontrolesysteem is beschreven, gaan we in op het metatoezicht door de NVWA: welke eisen heeft de NVWA gesteld voordat tot acceptatie van het systeem is overgegaan en op welke wijze houdt de NVWA daarna toezicht op het functioneren van het systeem? Onze aandacht gaat hierbij met name uit naar de vraag op welke wijze de NVWA tracht de aanwezige risico's te beheersen. De casusbeschrijvingen zijn gebaseerd op beschikbare documenten en interviews met personen betrokken bij het zelfcontrolesysteem, zowel van de kant van het zelfcontrolesysteem als van de kant van de NVWA. ${ }^{36}$ (red.), Handbook on the Politics of Regulation, Cheltenham: Edward Elgar 2011, p. 469-485.

36 We hebben vier interviews gevoerd: met de systeemdeskundige van RiskPlaza, met de technisch directeur van BDW verantwoordelijk voor de ontwikkeling van het keurmerksysteem, met een beslisser werkzaam bij een door RiskPlaza erkende certificatie-instelling en met de medewerker van de NVWA verantwoordelijk voor de ontwikkeling van zelfcontrolesystemen in horeca, ambacht, retail en zorg. Daarnaast hebben we gebruikgemaakt van eerder door een van de auteurs uitgevoerde interviews met de programmamanager op het gebied van levensmiddelen en voedselveiligheid van de NVWA en een medewerker van het Productschap Akkerbouw betrokken bij de ontwikkeling van RiskPlaza. 


\section{Bureau de Wit}

\section{Systeem}

BDW is een commercieel dienstverlenend bedrijf. Het bureau biedt controle en advies op het gebied van voedselveiligheid, waterveiligheid, luchtveiligheid en plaagdierpreventie. BDW is vijftig jaar geleden opgericht als laboratorium en heeft een eigen keurmerk voor voedselveiligheid en een geaccrediteerd laboratorium. De dienstverlening bestaat uit inspecties, training, monstername en analyse, consultancy, ontwikkelen van een kwaliteitssysteem. Klanten zijn werkzaam in onder meer de horeca, zorg, recreatie, catering en detailhandel.

Het BDW-zelfcontrolesysteem omvat minimaal twee inspectiebezoeken per jaar waarbij wordt getoetst of is voldaan aan de hygiënecode en regelgeving. Van elke inspectie wordt een gedetailleerd verslag gemaakt en er wordt een actieplan opgesteld. BDW zorgt voor begeleiding en follow-up van verbeterpunten. Locaties die minimaal twee achtereenvolgende inspecties boven de $80 \%$ scoren, zullen onder verminderd toezicht van de NVWA komen te staan en ontvangen het officiële BDW-keurmerk (inclusief vermelding op de website van BDW, keurmerklogo en sticker). Bedrijven sluiten een overeenkomst met BDW en geven daarbij toestemming aan BDW om de NVWA inzage te geven in de inspectieresultaten bij bijvoorbeeld een kantooraudit. ${ }^{37} \mathrm{Er}$ is geen convenant afgesloten tussen BDW en de NVWA. BDW informeert de NVWA alleen over bedrijven die goed scoren en in aanmerking komen voor verminderd toezicht door de NVWA. Deze bedrijven worden door de NVWA niet meer bezocht in het kader van een gewone steekproefcontrole; de NVWA maakt in dat geval gebruik van de BDW-beoordeling. ${ }^{38}$ De juridische basis voor de inspecties door BDW is een overeenkomst tussen BDW en het bedrijf. Het gaat om toezicht door een derde partij (een adviesbureau) op een eerste partij (de klant). In sommige gevallen heeft een tweede partij (een handelspartner) aangedrongen op deelname aan het zelfcontrolesysteem. Zo krijgen congreslocaties bij langer lopende contracten soms de vraag wat ze doen aan duurzaamheid, milieu of voedselveiligheid, maar vaak lijkt dit niet aan de orde. Tot de keurmerkklanten behoren diverse landelijke hotelketens (Bilderberg, Accor, NH, Stay Okay, Van der Valk), groentewinkels (De echte groenteman), restaurants (zelfstandige restaurants en Spare Rib Express), bedrijfskantines (Leo op het werk) en verpleeg- en verzorgingstehuizen. ${ }^{39}$ Het is opmerkelijk dat veel klanten met een BDW-keurmerk behoren tot ketens en franchiseorgani-

Overigens verplicht art. 8 van de Algemene Voorwaarden beide partijen tot geheimhouding van vertrouwelijke informatie. 'Informatie geldt als vertrouwelijk als dit door de andere partij is medegedeeld of als dit voortvloeit uit de aard van de informatie.' Andere opmerkelijke bepalingen zijn: art. 11-2, dat bepaalt dat 'alle door BDW verstrekte documenten zoals rapporten, adviezen, enz.' niet zonder voorafgaande schriftelijke toestemming van BDW door de opdrachtgever mogen 'worden verveelvoudigd, openbaar gemaakt, of ter kennis van derden worden gebracht.; art. 11-3, dat BDW het recht geeft om 'door de uitvoering van de werkzaamheden toegenomen kennis voor andere doeleinden te gebruiken, voor zover hierbij geen vertrouwelijke informatie ter kennis van derden wordt gebracht'; art. 13, dat de aansprakelijkheid van BDW beperkt. BDW, Inspectieprotocol Zelfcontrolesysteem BDW, 1-3-2012, versie 7 (website BDW).

39 BDW, Keurmerk voedselveiligheid, <www.bureaudewit.nl/keurmerk-overzicht.html> (24 oktober 2013). 
saties. Het hoofdkantoor van een keten- of franchisebedrijf stelt deelname verplicht om een bepaald kwaliteitsniveau in alle vestigingen te kunnen waarborgen en reputatieschade van de ketenmerknaam door een 'rotte appel' te voorkomen. Wanneer te veel filialen tijdens de inspectie door de NVWA als onvoldoende worden beoordeeld, krijgt de gehele keten een oranje (of rode) status vanwege de formuleaanpak van de NVWA. Dit is een extra reden voor formulebedrijven om mee te doen met het BDW-zelfcontrolesysteem omdat dan controles door de NVWA tot het verleden behoren.

Het normatieve toetsingskader van BDW is gelijk aan dat van de NVWA (conformiteit met de wettelijke normen i.c. de toepasselijke hygiënecode). Er is echter een verschil. Keurmeesters van BDW (en andere zelfcontrolesystemen) moeten alle vereisten van de hygiënecode bij een inspectie controleren, terwijl de NVWA de controle concentreert op bepaalde items. Bovendien is het vereiste niveau van naleving hoger: neemt de NVWA genoegen met een 6 , BDW en andere zelfcontrolesystemen mogen pas tevreden zijn met minimaal een 8. De medewerker van de NVWA zegt het zo:

'(...) de hygiënecodes (...) dat is een handzaam toetsdocument. Vervolgens (...) hoe ver wil je dat de ondernemer alles naleeft? Moet dat perfect zijn, een 10 , of mag het ook minder zijn? (...) wij hebben een interventiebeleid, dat moet je vergelijken met een zesje; als je een geringe overtreding hebt, noemen we dat nog steeds een zesje. (...) We willen wel dat jullie de lat eigenlijk net iets hoger leggen, dat je streeft naar een 8 en wij zijn tevreden met een 6 . (...) Als bureau, houdt dat dus in, wil je die 8 garanderen, dan moet je alles controleren. Wij maken keuzes, we prioriteren op onderwerp bijvoorbeeld. We zeggen, dat gaan jullie niet doen. Jullie gaan echt alles van A tot $\mathrm{Z}$ uit de hygiënecode helemaal doen. En dat moeten jullie helemaal op niveau hebben.'

Voorts is de frequentie van inspectiebezoeken door BDW hoger dan van de NVWA. De NVWA eist van een zelfcontrolesysteem een minimum van één onaangekondigd bezoek per jaar; BDW gaat daar overheen met minimaal twee bezoeken per jaar. Gemiddeld zegt BDW op elke locatie vier keer per jaar te komen.

In een onderzoek naar de betrouwbaarheid van voedselveiligheidscertificatie signaleert de NVWA dat sommige bedrijven niet gemotiveerd zijn om het eigen kwaliteitsniveau te verbeteren; zij zijn slechts geïnteresseerd in het certificaat (omdat de markt dit vereist). ${ }^{40}$ Zonder een intrinsieke motivatie is het risico groot dat bedrijven het niet meer nauw nemen met de voorschriften zodra de inspectie achter de rug is. Bovengenoemd onderzoek had geen betrekking op het BDW-keurmerk, maar op door de GFSI erkende voedselveiligheidsstandaarden. Dit risico lijkt bij BDW minder groot. Veel bedrijven werken al jarenlang samen met BDW om hun klanten goede kwaliteit te kunnen bieden. Bedrijven die zelf kiezen voor

40 Beuger 2012, p. 21. Dit wordt eveneens als kritisch punt genoemd bij de verplichte certificering op het terrein van arbeidsomstandigheden en veiligheid, G.I.J.M. Zwetsloot, S. Zwanikken \& A. Hale, Policy expectations and the use of markets mechanisms for regulatory OSH certification and testing regimes (CTRs), Safety Science 2011, p. 1007-1013 (1010). 
tamelijke intensieve controle en begeleiding en daar ook voor betalen, lijken gemotiveerd hun keuken goed georganiseerd te hebben. Het risico van onvoldoende motivatie is wel aanwezig wanneer bedrijven uitsluitend deelnemen aan het systeem omdat een transactiepartner of klanten hierop aandringen. Filiaalhouders of franchisenemers staan soms ook onder druk van het hoofdkantoor. In die gevallen is het vestigingsmanagement niet altijd echt gemotiveerd. Het is zelfs voorgekomen dat een vestigingsmanager niet bereid was om met BDW samen te werken.

'Het geeft wel eens vervelende situaties. Er zijn franchiseorganisaties die het verplicht stellen en de franchisenemer heeft zoiets van: alsjeblieft... (...) Dan mag het hoofdkantoor dat oplossen. Wij gaan de discussie op dat moment niet aan. Wij geven alleen maar aan: wij hebben opdracht van het hoofdkantoor en als de deur dicht gesmeten wordt, ja...' (BDW)

Onvoldoende medewerking met BDW kan negatieve consequenties hebben voor een vestiging. 'Het heeft er ook in geresulteerd dat bij bijvoorbeeld een keten een aantal ondernemers het logo niet meer mochten voeren. Dus die werden er gewoon uitgezet.' (BDW)

BDW speelt binnen een ketenformule een controlerende rol.

\section{Metatoezicht NVWA}

Hoe ziet het metatoezicht door de NVWA eruit? Voordat een zelfcontrolesysteem zoals dat van BDW door de NVWA geaccepteerd wordt, wordt een proces doorlopen dat minimaal twee jaar duurt. Het begint met een oriënterend gesprek. De beheerder van het zelfcontrolesysteem moet vervolgens nagaan of de eigen methodiek voldoet.

'Goed kijken naar wat je doet aan controles, hoe stel je vragen, wat voor norm leg je er tegenaan, hoe kijken jouw inspecteurs, hoe school je jouw inspecteurs, hoe geef je ze normen en referentiekaders en hoe waarborg je dat, hoe zit je berekening erachter, hoe verreken je alles dat er niks tussendoor glipt, hoe robuust is je systeem.' (medewerker NVWA)

Wanneer de NVWA en de beheerder van het systeem denken dat het systeem klopt, volgt een 'adressentoets'. De beheerder levert de NVWA minimaal veertig adressen die naar zijn oordeel voldoende niveau hebben. De NVWA kijkt vervolgens hoe die bedrijven bij haar bekendstaan. Als dit goed is, volgt een kantooraudit. Twee niet bij de eerdere gesprekken betrokken NVWA-auditoren checken het systeem en beoordelen inspectierapporten. De volgende stap is dat het zelfcontrolesysteem bedrijven gaat benaderen om deel te nemen. Wanneer er honderd bedrijven meedoen, doet de NVWA een 'reality check' om na te gaan of het systeem ook in de praktijk een hoog niveau van naleving biedt. Wanneer er dan onverklaarbare verschillen aan het licht komen, kan de NVWA als extra stap bedrijven inspecteren onmiddellijk nadat de inspecteur van het zelfcontrolesysteem is geweest om te bezien of dezelfde situatie hetzelfde wordt beoordeeld. Als 
al deze stappen naar tevredenheid zijn doorlopen accepteert de NVWA het zelfcontrolesysteem en vermeldt dit op haar website.

De NVWA heeft bij aanvang van het traject geïnteresseerde bureaus geen duidelijke lijst met criteria gegeven waaraan een zelfcontrolesysteem moet voldoen voor acceptatie. De NVWA wilde, mede gezien de ervaringen met het eerdere programma Toezicht op controle, ${ }^{41}$ geen vooraf vastgesteld stramien aan alle bureaus opleggen en ruimte bieden aan verschillende systemen. 'En dan hebben wij geluk gehad want wij weten waar een bepaalde systematiek aan moet voldoen. Denk aan basiszaken als werkhouding, opleiding, positieve en integratieve maatregelen, nou goed. Dat lag allemaal al vast bij ons.' (BDW)

Volgens de NVWA zijn uiteindelijk de volgende eisen gesteld aan zelfcontrolesystemen zoals Bureau de Wit:

1. Deelnemende bedrijven voldoen aan de NVWA-definitie van ambachtelijk bedrijf.

2. Deelnemende bedrijven borgen voedselveiligheid volledig door te werken met een goedgekeurde hygiënecode; bedrijven met een eigen aanvulling op de hygiënecode kunnen niet meedoen.

3. Bij inspectie moeten alle elementen van de hygiënecode van $A$ tot $Z$ worden gecontroleerd.

4. Norm van een 8 .

5. Ingebouwd correctiemechanisme: bij geconstateerde overtredingen is herinspectie verplicht.

6. Minimaal één keer per jaar inspectie.

7. Inspecties zijn onaangekondigd.

8. Deelnemende bedrijven moeten formeel toestemming geven voor uitwisseling van inspectiegegevens tussen NVWA en het zelfcontrolesysteem.

Accreditatie is geen vereiste. Ook stelt de NVWA geen concrete eisen aan opleiding en ervaring van de auditor, hoewel dit wel onderdeel is van de audit door de NVWA. Een organisatorische scheiding tussen audit en advies is evenmin een harde eis, maar het ontbreken ervan roept wel vragen op bij de NVWA.

BDW geeft - evenals de zes andere door de NVWA geaccepteerde zelfcontrolesystemen - maandelijks aan de NVWA door welke bedrijven deelnemen aan zijn systeem. De NVWA gaat ervan uit dat die bedrijven voldoende naleving hebben en bezoekt die bedrijven niet meer. Het toezicht van de NVWA op het individuele bedrijf vervalt. De NVWA gebruikt de inspectieresultaten van het zelfcontrolesysteem.

Het is nog niet helemaal duidelijk op welke manier de NVWA toezicht gaat houden op eenmaal geaccepteerde zelfcontrolesystemen. Naar verwachting zal dit naast een jaarlijks gesprek afwisselend bestaan uit een kantooraudit en een steekproefsgewijze controle bij deelnemende bedrijven om het systeem te toetsen.

41 Ministerie van Landbouw, Natuur en Voedselkwaliteit, Toezicht op controle (Beleidskader, Den Haag 2005) en H. van der Voort, Naar een drie-eenheid van co-regulering: Over spanningen tussen drie toezichtregimes (diss. Delft), Nootdorp: Sandedruk 2013, p. 102 e.v. 
'Tenzij het een ernstige overtreding is waar we echt niet aan voorbij kunnen lopen, maar anders is het zo dat we zeggen, "Oké, we constateren dat er sprake is van een overtreding." We handhaven niet, want daar is het ons niet om te doen, maar we hebben het wel vastgelegd, we hebben het rapport van de betreffende instelling gevraagd om te kijken wat zij hebben gevonden en wat is er daarna gedaan om het systeem zijn werk te laten doen.' (NVWA)

Minimaal twee keer per jaar heeft de NVWA overleg met alle geaccepteerde zelfcontrolesystemen over nieuwe ontwikkelingen en de rol van de systemen naar aanleiding van ervaringen (bijvoorbeeld met wederzijdse rollen in geval van een voedselvergiftiging bij een deelnemend bedrijf).

\section{Riskplaza}

\section{Systeem}

RiskPlaza is een systeem voor de borging van risico's en gevaren voor voedselveiligheid van ingrediënten. Het werd in 2008 opgezet door het Productschap Akkerbouw (PA) om naleving van HACCP-beginselen door MKB'ers in de bakkerijsector te verbeteren. Riskplaza, dat thans beschikbaar is voor de gehele levensmiddelenindustrie, bestaat uit twee elementen: een database met informatie over de gevaren voor voedselveiligheid van ingrediënten en het zogenoemde 'RiskPlaza-audit+'-systeem. De informatie in de gevarendatabase betreft een uitwerking van EU- en Nederlandse wet- en regelgeving over voedselveiligheid en wordt opgesteld en geactualiseerd door het PA in samenwerking met deskundigen uit de diverse sectoren van de levensmiddelenindustrie, de NVWA en de bij het auditsysteem betrokken certificatie-instellingen. Bedrijven in de levensmiddelenketen (en de aangesloten certificatie-instellingen) kunnen de database raadplegen bij hun (extern toezicht op de) borging van de voedselveiligheidsrisico's van ingrediënten. ${ }^{42}$ In een convenant met de NVWA is overeengekomen dat de NVWA zich bij haar toezicht zal verlaten op de informatie zoals die in de database staat, opdat een 'gezamenlijk uitgangspunt' bestaat over welke gevaren kunnen voorkomen in de ingrediënten. ${ }^{43}$ Per 1 januari 2014 zijn de productschappen opgeheven en om het bestaan van RiskPlaza te garanderen, is het systeem sindsdien ondergebracht

42 PA, RiskPlaza, <www.riskplaza.nl/riskplaza/pagina/100047/wat-is-riskplaza.aspx> (30 augustus 2013).

43 Convenant horizontaal toezicht tussen het Productschap Akkerbouw (systeemeigenaar RiskPlaza) en de Nederlandse Voedsel- en Warenautoriteit (verder: Convenant RiskPlaza 2012), Stcrt. 2012, 13450, onder 'Doelen en uitgangspunten', nr. 7. 
bij Stichting RiskPlaza en RiskPlaza BV. ${ }^{44}$ Het is op dit moment nog onduidelijk welke consequenties deze wijziging zal hebben voor het functioneren van RiskPlaza en de convenanten met de NVWA.

Het 'RiskPlaza-audit+'-systeem is een auditsysteem dat als doel heeft leveranciers en afnemers in de levensmiddelenindustrie te ondersteunen bij het voldoen aan de geldende wet- en regelgeving betreffende inkoopverificatie van voedselveiligheid van grondstoffen en ingrediënten. ${ }^{45}$ Hoewel de audits door certificatieinstellingen worden uitgevoerd, ziet het PA het auditsysteem niet als een certificatieschema: wanneer een leverancier aan de eisen voldoet, wordt er geen certificaat verleend, maar slechts de status van 'RiskPlaza-audit+'. ${ }^{46}$ Afnemers kunnen van een leverancier verlangen dat zij deze status verwerven. Zodoende is het auditsysteem een vorm van toezicht door een derde partij (een certificatieinstelling) op een eerste partij (de leverancier) al dan niet op aandringen van een tweede partij (een afnemer). Omdat de audit plaatsvindt op basis van de RiskPlaza gevarendatabase, die mede is opgesteld door de NVWA, is er tevens sprake van inmenging van een vierde partij.

De voorwaarden om de status van RiskPlaza-audit+ te verkrijgen worden gedetailleerd beschreven in het 'Auditreglement'. ${ }^{47}$ Een leverancier kan zich bij een deelnemende certificatie-instelling aanmelden voor een RiskPlaza-audit+-controle, waarna hij een contract sluit voor het uitvoeren van auditdiensten. Tijdens de audit moet hij aantonen dat alle gevaren van de door hem verhandelde producten - zoals beschreven in de RiskPlaza-database - zijn geborgd. De audit wordt slechts uitgevoerd indien de leverancier reeds in bezit is van een geldig voedselveiligheidscertificaat, zoals Dutch HACCP, IFS, BRC, ISO 22000, FSSC 22000 of een door de NVWA goedgekeurde hygiënecode. ${ }^{48}$ Daar waar deze certificaten zien op de beoordeling van voedselveiligheid in het productieproces, is de RiskPlazaaudit+ een aanvullende toetsing - vandaar de ' + ' - die specifiek gericht is op de

44 Op de RiskPlaza-website wordt de nieuwe organisatie als volgt omschreven: 'In Stichting Riskplaza vinden de overleggen plaats tussen deskundigen en belangenbehartigers van de verschillende sectoren uit de voedingsindustrie, de certificerende instellingen en [de] NVWA. (...) Het bestuur van de Stichting bestaat uit 4 personen en is samengesteld uit vertegenwoordigers van Riskplaza zelf, de [certificerende instellingen], de sectoren en een onafhankelijke derde. Het bestuur zal in de loop van februari 2014 worden geïnstalleerd. Naast het bestuur is er een Raad van Sectoren ingesteld als speciaal overleg- en adviesorgaan aan het bestuur. In deze Raad zijn o.a. vertegenwoordigd de NVB, de VBZ, de NBOV, Nepluvi, de KNVKT, Nebafa, de NVM en de VNV. Riskplaza BV is faciliterend aan Stichting Riskplaza en heeft als taak om het dagelijkse management van de Stichting te verzorgen en om support te bieden o.a. richting de abonnementhouders en de Audit+-erkende bedrijven. Tevens verzorgt Riskplaza BV de financiële en administratieve afwikkeling van de hele organisatie.' RiskPlaza, Organisatie <www.riskplaza.nl/ riskplaza/pagina/100043/organisatie.aspx> (8 januari 2014).

45 Art. 5 Verordening 2004/852/EG inzake levensmiddelenhygiëne, zoals door de NVWA vertaald in Informatieblad 64 (versie april 2013 <www.vwa.nl/txmpub/files/?p_file_id=10378>) (30 augustus 2013).

46 PA, Auditreglement RiskPlaza-audit ${ }^{+}$systeem (versie 2.0, maart 2013, Den Haag) (hierna: Auditreglement 2013), <www.productschapakkerbouw.nl/files/PA_28032013_B14.pdf>(30 augustus 2013).

47 Ibid., p. 23.

48 Ibid., p. 6. 
beheersing van de voedselveiligheid op het niveau van ingrediënten. ${ }^{49}$ De beoordeling die plaatsvindt, is vooral een administratieve toets:

'Tijdens een audit doen wij geen onderzoeken, tenminste er worden geen monsters genomen, er worden geen analyses uitgevoerd. Wij kijken uiteraard wel naar wat een bedrijf zelf doet aan monstername en analyses en kwaliteitscontroles. (...)' (certificatie-instelling aangesloten bij RiskPlaza)

Privaat toezicht bestaat voornamelijk daaruit dat wordt gecontroleerd of de registratie en analyseresultaten van het bedrijf voor de borging van gevaren correct zijn. Deze controle vindt plaats op basis van aangekondigde bezoeken. Hoewel de nieuwe versie van het Auditreglement de mogelijkheid geeft onaangekondigde audits uit te voeren, ${ }^{50}$ merkt een medewerker van een aangesloten certificatieinstelling op:

'Onaangekondigd zou denk ik niet zo goed werken. Het heeft voor RiskPlaza in ieder geval geen toegevoegde waarde. Als we kijken naar het systeem van borging hoe dat ingericht is, en dat ga je verifiëren terug in de tijd. Dat zal bij dat soort dingen bijna altijd aan de hand van documenten zijn die er al dan niet zijn.'

Indien een afnemer zijn grondstoffen en ingrediënten betrekt van een leverancier die voldoet aan het RiskPlaza-audit+-systeem, dan voldoet hij daarmee automatisch aan de wettelijke verplichting tot inkoopverificatie en is een aparte verificatie op de producten van die leverancier niet meer noodzakelijk. In beginsel vervalt dan de controle van de NVWA bij de afnemer op dit punt. ${ }^{51}$ Ook de NVWAcontrole bij de RiskPlaza Audit+ gecontroleerde leverancier vervalt op dit punt. ${ }^{52}$ De NVWA kan dan nog wel bij de afnemer en leverancier langskomen voor toezicht op andere aspecten van voedselveiligheidsregelgeving.

Thans hebben 53 bedrijven de status van RiskPlaza-audit+-bedrijf. ${ }^{53}$ De audits worden normaliter tijdens of na een reguliere HACCP-voedselveiligheidsaudit uitgevoerd. Een audit wordt minimaal eenmaal per jaar uitgevoerd en de frequentie is daarmee doorgaans gelijk met de reguliere HACCP-audits. ${ }^{54}$ Het PA heeft vier certificatie-instellingen erkend die de RiskPlaza-audits mogen uitvoeren. ${ }^{55}$ De voorwaarden die gelden voor erkenning worden door een 'systeemdeskundige'

Ibid., p. 20.

Er moet dan een situatie zijn 'waarbij de voedselveiligheid in het geding is door onvoldoende beheersing van grondstoffen'. Auditreglement 2013, p. 24.

Convenant RiskPlaza 2012, onder 'Verplichtingen NVWA', nr. 4

Convenant RiskPlaza 2012, onder 'Verplichtingen NVWA', nr. 5.

Peildatum is 30 augustus 2013. Zie voor de actuele lijst: PA, RiskPlaza-audit+-bedrijven, <www.riskplaza.nl/riskplaza/Rapportage/Bedrijven/BedrijvenOverzicht.aspx?1>.

Auditreglement 2013, p. 24.

Peildatum is 30 augustus 2013. Zie voor de actuele lijst: PA, Certificerende Instellingen, <www.riskplaza.nl/riskplaza/Rapportage/Certificerendeinstellingen/Certificerendeinstellingen

Overzicht.aspx?1>. 
getoetst. ${ }^{56}$ Deze interne deskundige evalueert tevens de prestaties van de certificatie-instellingen op aspecten als volledigheid, consistentie en kwaliteit en rapporteert hier jaarlijks over. Met dat doel verzamelt zij de rapportages van de certificatie-instellingen en woont zij audits van de instellingen bij ('bijwoningen'). ${ }^{57}$

\section{Metatoezicht NVWA}

Hoe heeft de NVWA haar toezicht op RiskPlaza ingericht? Nu zij zich door middel van een convenant heeft verbonden om zich bij inspecties van borging van voedselveiligheid te laten leiden door de RiskPlaza-database en haar inspectieactiviteiten bij bedrijven met de RiskPlaza-audit+-status en hun afnemers beperkt, is een deugdelijke toets op het private systeem van groot belang. Op verscheidene manieren kleurt de NVWA haar metatoezicht in.

In de eerste plaats is de NVWA nauw betrokken geweest bij de totstandkoming van RiskPlaza. Toen in 2005 de eerste gesprekken plaatsvonden tussen het PA en de bakkerijsector was de NVWA reeds gevraagd om betrokken te zijn bij de opzet van een privaat systeem van borging van ingrediënten en grondstoffen. Ook thans heeft de NVWA een formele rol in het beheer en de organisatie van RiskPlaza doordat ze deelneemt aan het zogenoemde 'deskundigenoverleg'. ${ }^{8}$ Dit overleg bepaalt de inhoud van de gevarendatabase en stelt de ingrediëntgroepen en factsheets van de daaraan gekoppelde gevaren vast. In het overleg worden ook actualiteiten en gewijzigde wet- en regelgeving op het gebied van voedselveiligheid van ingrediënten uitgewisseld. ${ }^{59}$ Deelname aan het deskundigenoverleg, dat maximaal vier keer per jaar plaatsvindt, stelt de NVWA in staat een vinger aan de pols te houden ten aanzien van de materiële voorschriften op basis waarvan de RiskPlaza-audits plaatsvinden. Aldus kan zij toezien op het beschermingsniveau dat RiskPlaza beoogt na te streven en ervoor zorgen dat wijzigingen in wet- en regelgeving bijtijds en correct worden verwerkt.

Ten tweede neemt de NVWA ook deel aan het zogenoemde 'harmonisatieoverleg' dat jaarlijks plaatsvindt tussen de auditoren en coördinatoren van de erkende certificatie-instellingen en de RiskPlaza-systeemdeskundige. ${ }^{60}$ Tijdens deze bijeenkomst koppelt de systeemdeskundige terug wat zijn bevindingen zijn van de rapportages van certificatie-instellingen en de uitgevoerde 'bijwoningen'. Tevens worden casus besproken, niet zozeer op het niveau van resultaten van individuele certificatie-instellingen maar gevallen waarin de aanpak voorbeeldig of juist bedenkelijk is. Daar waar deelname aan het deskundigenoverleg de NVWA inzicht geeft in het materiële beschermingsbereik van het RiskPlaza-systeem, voorziet deelname aan het harmonisatieoverleg de NVWA juist van actuele informatie over de wijze waarop het private toezicht wordt uitgeoefend. Gesteld kan worden dat de NVWA dus nauw betrokken is bij het beheer en de organisatie van het RiskPlaza-systeem. 
Voorts stelt de informatie-uitwisseling tussen de NVWA en het PA de NVWA in staat toezicht te houden op het functioneren van RiskPlaza en het RiskPlazaaudit+-systeem. Het convenant tussen de NVWA en het PA verplicht de laatste om significante wijzigingen in het systeem tijdig te melden aan de NVWA, haar toegang te geven tot de RiskPlaza-database en inzicht te geven in de werking van het audit+-systeem. ${ }^{61}$ Vanuit het publieke belang gezien is het opmerkelijk om te constateren dat er geen verplichting bestaat voor het PA om informatie te verstrekken over situaties die certificatie-instellingen bij bedrijven hebben geconstateerd die de voedselveiligheid in gevaar brengen. ${ }^{62}$ De rapportages van de instellingen worden ook niet automatisch gedeeld met de NVWA en zij heeft ook niet bedongen dat het PA de aangesloten instellingen daartoe verplicht. Een medewerker van een aangesloten audit-instelling zegt hierover:

'We hebben gewoon een vertrouwelijkheidrelatie met onze klanten. Dat is in feite de basis voor ons bestaan. Alles wat er tijdens zo'n audit gezegd wordt en alle informatie die een auditor te horen krijgt, ziet of leest of op een andere manier te weten komt, dat is gewoon vertrouwelijk. Dat komt alleen maar in het rapport te staan en het rapport is in feite het eigendom van onze opdrachtgever, onze klant. En niemand anders krijgt dat te zien. Een paar uitzonderingen, maar ook daarbij is er sprake van een vertrouwelijkheidrelatie. De systeemdeskundige [van RiskPlaza] die mag de rapporten opvragen om ze in te zien en te beoordelen voor wat haar functie is. Als het bedrijf dat rapport wil delen met anderen dan mogen ze dat doen, het is hun eigendom.'

Niettemin zijn er verschillende manieren waarop de NVWA inzicht kan krijgen in de naleving door bedrijven met de RiskPlaza-audit+-status. Ten eerste kan de NVWA de website van RiskPlaza monitoren op eventuele wijzigingen. ${ }^{63}$ De NVWA kan tevens de rapportages bij het bedrijf opvragen indien zij voor een inspectie langskomt. Voorts krijgt de NVWA op systeemniveau inzicht in de prestaties van bedrijven door deel te nemen aan het harmonisatieoverleg. Ten slotte kan de NVWA zich inzicht verschaffen door het doen van een systeemaudit. In dat geval evalueert zij de gehele werking van de RiskPlaza-database en het RiskPlaza-audit+-systeem. Het convenant tussen het PA en de NVWA voorziet in die mogelijkheid, ${ }^{64}$ maar sinds de lancering van RiskPlaza in 2008 is daar nog geen gebruik van gemaakt. De systeemaudit zou dan de vorm aannemen van een administratieve toets waarbij de documenten en procedures op basis waarvan RiskPlaza en het auditsysteem opereren worden geëvalueerd. Het convenant geeft aan dat in dat geval ook inzicht kan worden verkregen in het functioneren van het systeem door middel van inzage van de auditrapportages en een steekproef bij

61 Convenant RiskPlaza 2012, onder 'Verplichtingen PA', nrs. 2, 5 en 7.

62 Het convenant voorziet alleen in de situatie dat de NVWA informatie mag verstrekken aan het PA over situaties bij bedrijven waarbij de voedselveiligheid in het geding is door onvoldoende beheersing van de grondstoffen. Zie Convenant RiskPlaza 2012, onder 'Verplichtingen PA', nr. 8. Het PA is verplicht tot publicatie van de RiskPlaza-audit+-bedrijven in een openbaar register op <www.riskplaza.nl>. Zie Convenant RiskPlaza 2012, onder 'Verplichtingen PA', nr. 6. 
de bedrijven met de RiskPlaza-audit+-status. ${ }^{65}$ Ten tijde van de interviews bestond er geen helderheid over de inhoud en methodiek van deze toetsing door de NVWA.

\section{Vergelijking en discussie}

\section{Systeem}

Er is een aantal overeenkomsten tussen de beide onderzochte zelfcontrolesystemen. Zowel RiskPlaza audit+ als BDW werkt met een 100\% controle: alle gevaren van alle grondstoffen respectievelijk alle elementen van de hygiënecode moeten worden gecontroleerd. Bij beide systemen is sprake van toezicht door een externe auditor op basis van een normdocument en vastgelegde controlesystematiek. Ook stelt in beide systemen de auditor een rapport op en neemt iemand anders binnen de organisatie (de certificatie-instelling of BDW) de beslissing omtrent goedkeuring. De scheiding van audit- en goedkeuringsfuncties draagt bij aan een grotere mate van onafhankelijkheid waarmee het private toezicht wordt uitgeoefend.

Er zijn echter ook een aantal verschillen. Dit betreft bijvoorbeeld de normen. RiskPlaza kan worden gezien als een vorm van co-regulering. ${ }^{66}$ De NVWA stelt samen met het Productschap Akkerbouw en andere betrokkenen de normen vast en legt die neer in de gevarendatabase op basis waarvan via het RiskPlazaaudit+-systeem het toezicht door de certificatie-instellingen wordt uitgeoefend. In het geval van BDW is er geen sprake van overleg met de NVWA ten aanzien van de getoetste norm. Dit is een hygiënecode opgesteld door de relevante brancheorganisatie en goedgekeurd door de minister (NVWA). BDW heeft geen rol in de vaststelling van deze codes.

Een ander verschil is dat controles door BDW het toezicht van de NVWA op individuele bedrijven volledig vervangen. De NVWA voert zelf geen controles meer uit bij de klanten van BDW (tenzij in het kader van een systeemaudit) en gaat uit van het auditrapport door BDW. Bij RiskPlaza is daarentegen slechts sprake van een gedeeltelijke vervanging van het NVWA-toezicht, namelijk ten aanzien van de risicobeheersing van grondstoffen. De NVWA blijft de RiskPlaza-audit+-bedrijven en hun afnemers controleren ten aanzien van alle andere aspecten van voedselveiligheid. Een RiskPlaza audit+ is een aanvullende controle naast een reeds aanwezig voedselveiligheidscertificaat. Een verschil tussen beide systemen in de uitvoering van toezicht is dat BDW zelf de feitelijke inspecties uitvoert, terwijl RiskPlaza vier geaccrediteerde certificatie-instellingen heeft erkend om de audits uit te voeren bij de deelnemende bedrijven.

Dit betekent een verschil in de keten van toezicht in beide systemen. In het geval van BDW houdt de NVWA toezicht op BDW en BDW houdt toezicht op de deelnemende bedrijven. Bij RiskPlaza houdt de NVWA toezicht op het RiskPlazasysteem, zowel wat betreft de database als het auditsysteem, houdt RiskPlaza 
toezicht op de erkende certificatie-instellingen, en houden de certificatie-instellingen vervolgens toezicht op deelnemende bedrijven. Een consequentie van de keuze om de audit door geaccrediteerde certificatie-instellingen te laten uitvoeren, is dat certificatie-instellingen niet alleen te maken hebben met de eisen die RiskPlaza stelt, maar ook met die van accreditatie-instellingen. Zo moet bijvoorbeeld sprake zijn van een strikte scheiding tussen audit en advies. BDW is niet geaccrediteerd voor certificatieactiviteiten en dat geeft BDW meer ruimte om advies te geven aan zijn klanten tijdens een bezoek.

Een laatste verschil in de uitvoering van toezicht betreft de aard van de controles. Een RiskPlaza-audit is vooral een administratieve controle, terwijl BDW niet alleen de documentatie van een klant (THTs, temperatuurregistratie, schoonmaaklijsten) controleert, maar bijvoorbeeld ook monsters neemt en 'alle hoekjes' van de keukens inspecteert. Keurmeesters van BDW komen minimaal twee keer per jaar onaangekondigd bij keurmerkklanten, terwijl een RiskPlazaaudit+-bezoek eens per jaar plaatsvindt en vooraf is aangekondigd.

\section{Metatoezicht}

Bij zowel BDW als RiskPlaza had de NVWA niet vooraf een heel duidelijk eisenpakket; gaandeweg zijn de eisen voor NVWA-acceptatie uitgekristalliseerd. Bij zelfcontrolesystemen zoals BDW heeft dit geleid tot een aantal duidelijke voorwaarden die ook bij vergelijkbare initiatieven gelden. RiskPlaza is daarentegen een uniek systeem. Een opmerkelijk verschil betreft de eis aan systemen zoals dat van BDW dat inspecties altijd onaangekondigd moeten zijn, terwijl bij RiskPlaza die eis niet is gesteld. In beide gevallen heeft de NVWA voorafgaand aan de acceptatie van het systeem het systeem geaudit en zijn steekproefonderzoeken gedaan bij bedrijven om te controleren of het systeem goed werkt, dat wil zeggen dat er geen grote afwijkingen tussen de controleresultaten van het systeem en van de NVWA zijn geconstateerd. Het is nog te vroeg om duidelijke conclusies te trekken over het NVWA-toezicht nadat de systemen zijn geaccepteerd. De NVWA heeft de bedoeling in beide gevallen een vinger aan de pols te houden via geregeld overleg, systeemaudits en steekproefcontroles.

Er is ook een aantal wezenlijke verschillen. Zo heeft de NVWA de mogelijkheid om op ieder moment een auditrapport van een klant van BDW op te vragen. De NVWA verplicht BDW om zich door zijn klanten te laten machtigen om de NVWA volledige inzage te geven in de auditresultaten. Bij RiskPlaza kunnen de auditrapporten alleen in het kader van een steekproef of een systeemaudit worden gedeeld met de NVWA. De certificatie-instellingen aangesloten bij het RiskPlazaaudit+-systeem nemen in hun contracten geen mogelijkheid op om auditresultaten door te spelen aan de NVWA en RiskPlaza verplicht hen dat ook niet. ${ }^{67}$ De certificatie-instellingen hechten aan hun vertrouwensrelatie met de klant. De NVWA krijgt inzicht in de auditresultaten indien zij het bedrijf bezoeken en de resultaten dan ter plaatse opvragen. Wel is RiskPlaza verplicht een openbaar register te hebben van RiskPlaza-audit+-bedrijven. Bij BDW bestaat die verplich-

67 Het convenant tussen de NWVA en RiskPlaza legt geen verplichting op RiskPlaza om een dergelijke mogelijkheid te creëren. 
ting niet. In de praktijk is het verschil minder groot. BDW heeft op de website een lijst met bedrijven die het keurmerk hebben (indien de klant instemt met vermelding).

\section{Risico's aan metatoezicht}

Welke risico's kleven er aan het metatoezicht zoals de NVWA dat thans heeft ingericht bij BDW en RiskPlaza? Een eerste punt van zorg is de mogelijkheid van belangenverstrengeling bij de private toezichthouders en onder toezicht gestelde bedrijven. Zowel BDW als certificatie-instellingen worden betaald door de klanten die zij controleren en hebben dus een financieel belang bij het in stand houden van de relatie met hun klanten. BDW en de certificatie-instellingen aangesloten bij RiskPlaza balanceren bij hun controles steeds tussen enerzijds het belang om streng en oprecht te controleren op overtredingen en anderzijds het belang van het onderhouden van een gezonde commerciële relatie met hun klanten.

'Je zou op certificaten moeten kunnen vertrouwen. Mijn kennis en kunde zegt dat ik dat op dit moment nog niet voldoende kan. Er zijn certificatieinstellingen die het goed doen, maar het is natuurlijk voor certificatie-instellingen lastig want ze moeten hun klanten ook tevreden houden en die willen een certificaat.' (RiskPlaza)

Te streng toezicht kan ertoe leiden dat (potentiële) klanten kiezen voor een andere aanbieder. Te soft toezicht kan leiden tot een gebrek aan vertrouwen in een certificaat of keurmerk; hiermee verliest een certificaat of keurmerk zijn waarde. ${ }^{68}$ Het kan ook het verlies van NVWA-acceptatie in het geval van BDW of van erkenning door RiskPlaza in het geval van de certificatie-instellingen tot gevolg hebben.

De bij RiskPlaza aangesloten certificatie-instellingen zijn geaccrediteerd en accreditatie eist dat controle en advies strikt gescheiden blijven. Ook BDW vindt een scheiding tussen controle en advies belangrijk. Echter, de scheidslijn tussen toezicht en advies is bij BDW meer diffuus. Het bureau helpt bedrijven om te voldoen aan de hygiëneregels door toelichting te geven op geconstateerde tekortkomingen en door het verzorgen van trainingen. Het nadeel hiervan kan zijn een grotere betrokkenheid bij degenen die gecontroleerd worden en daardoor een soepeler beoordeling. Zowel BDW als de NVWA ziet overigens wel voordelen in de combinatie van keuring en advies in de horeca, ambacht en zorgsector. Het maakt de controles laagdrempeliger en er kan op een informele wijze gewezen worden op verbeterpunten bij de veelal kleinere bedrijven. Uiteindelijk wordt hiermee wellicht een hoger niveau van naleving bereikt dan met een strikte controle zonder uitleg, advies en hulp.

68 Zwetsloot e.a. constateerden eerder dat certificatie-instellingen op het terrein van occupational safety and health over weinig echte sanctiemogelijkheden beschikken. Uitstel voor de verlening van het certificaat is een reële optie, maar de intrekking van een certificaat blijkt weinig voor te komen en alleen wanneer bedrijven hun rekening niet betalen (en niet bij onvoldoende functioneren). Dit geeft te denken over het regulerend vermogen van certificatie- en keuringsinstellingen en de betrouwbaarheid van de betrokken systemen. Zie Zwetsloot e.a. 2011, p. 1011. 
Een tweede risico betreft de motivatie van bedrijven om zich door zelfcontrolesystemen als BDW en RiskPlaza te laten controleren. Het is niet altijd een intrinsieke drive tot betere naleving van voedselveiligheidsvoorschriften, maar soms ook druk van buitenaf die zorgt dat bedrijven zich bij BDW of een certificatieinstelling melden. In het geval van RiskPlaza komt deze druk van afnemers omdat zij dan zelf geen aparte inkoopverificatie meer hoeven te verrichten of omdat hun eigen afnemers, zoals supermarkten, willen dat zij werken met grondstoffen van RiskPlaza-bedrijven:

'Omdat steeds meer klanten het gaan vragen. Maar de hoeveelheid is eigenlijk nog heel laag. Je zou hopen dat dat meer zou worden. Maar ik denk dat daar ook in zit dat mensen zich nog niet realiseren dat wat ze voor RiskPlaza moeten doen, eigenlijk minder is dan wanneer ze het niet hebben. (...) En het begint natuurlijk toch met supermarkten. Wat dat betreft is de beweging wel goed. Zij vragen soms van hun leveranciers om in zee te gaan met RiskPlazagecontroleerde bedrijven.' (RiskPlaza)

BDW heeft veel ketens als klant die door deelname onder andere de NVWAinspecties willen vermijden. Vestigingsmanagers worden verplicht deel te nemen aan het systeem en zijn niet altijd gemotiveerd om de voedselveiligheid op een hoger plan te brengen. Het ontbreken van de juiste motivatie kan leiden tot onvoldoende aandacht voor voedselveiligheid wanneer de controle achter de rug is. ${ }^{69}$ Dit risico wordt in het geval van BDW deels ondervangen doordat de controles onaangekondigd plaatsvinden en door minimaal twee en gemiddeld vier controlebezoeken per jaar. Overigens zijn ook managers van bedrijven die niet deelnemen aan een zelfcontrolesysteem niet altijd gericht op een optimale voedselveiligheidssituatie.

Een derde punt van zorg is dat het eerstelijnstoezicht van de NVWA niet frequent genoeg is om bedrijven te prikkelen zich bij geaccepteerde private systemen aan te sluiten. De bedrijven die vrijwillig deelnemen aan deze systemen hebben geïnvesteerd in een betere naleving van voorschriften. Om de concurrenten te kunnen dwingen zich ook aan te sluiten, zou daar tegenover moeten staan dat de NVWA bij die bedrijven vaker langskomt. De vraag is echter of de NVWA dit door de voortgaande bezuinigingsrondes kan realiseren.

'Waarschijnlijk niet. Het is wel zo dat we, kijk, vanuit de openbaarmaking worden bedrijven dadelijk toch veel beter zichtbaar. Dus in hoeverre we echt degenen die het nodig hebben... we maken selecties, we kunnen gewoon niet overal naartoe, ook dadelijk niet. We maken selecties waarvan we wel zeggen, " $100 \%$ van die groep en $100 \%$ van die groep en die groep laten we even zitten." Zo'n groep die we dan laten zitten bijvoorbeeld, die komt er heel makkelijk vanaf. Die heeft helemaal niks, dat is zo. (...)' (NVWA) 
Aldus ontstaat er een free rider-probleem: niet-deelnemende bedrijven worden minder vaak gecontroleerd en hebben minder kosten dan de deelnemende bedrijven. Dit is een heikel punt van de publiek-private samenwerking die het metatoezicht impliceert. Anderzijds biedt deelname aan een door de NVWA geaccepteerd zelfcontrolesysteem bedrijven wellicht de mogelijkheid om zich positief te onderscheiden van hun concurrenten. Wanneer deelname verplicht zou worden gesteld, vervalt dit voordeel en verdwijnt de stimulans om beter te presteren. ${ }^{70}$ De NVWA gaat ervan uit dat slechts een deel van de bedrijven zich vrijwillig zal aansluiten bij een zelfcontrolesysteem zoals Bureau de Wit en dan met name bedrijven die goed willen presteren en zich op kwaliteit willen onderscheiden.

Een vierde risico betreft de verplichting tot informatie-uitwisseling tussen zelfcontrolesystemen en de NVWA. Hoewel de NVWA zich op verschillende manieren heeft verzekerd van toegang tot actuele informatie over de resultaten van bezoeken, keuringen en inspecties uitgevoerd door BDW en de bij RiskPlaza aangesloten certificatie-instellingen, bestaat er voor deze private toezichthouders geen actieve verplichting om informatie te verstrekken aan de NVWA over ernstige inbreuken op voedselveiligheidsregels of acuut gevaar voor de volksgezondheid. De informatievoorziening tussen de NVWA en de zelfcontrolesystemen berust thans geheel op het monitoren door de NVWA van de output die deze systemen genereren.

In deze rolverdeling schuilt het risico dat eventuele overtredingen onopgemerkt blijven voor de NVWA. Het voortdurend bijhouden van eventuele wijzigingen doet een extra beroep op de middelen van de NVWA, terwijl die nu juist teruglopen. Eerder werd gesignaleerd dat een adequaat systeem van informatie-uitwisseling een noodzakelijke voorwaarde is voor een effectieve samenwerking tussen publieke en private partijen. ${ }^{71}$ In een recent onderzoek uitgevoerd in opdracht van de Britse Food Standards Agency wordt ook gesteld dat het ontbreken van een actieve plicht voor geaccepteerde private controlesystemen om informatie te verstrekken over ernstige inbreuken op voedselveiligheidsregels of acuut gevaar voor de volksgezondheid het handhavingsvermogen van lokale autoriteiten in belangrijke mate kan ondermijnen. ${ }^{72}$ De NVWA zou er goed aan doen om een dergelijke plicht op te nemen als criterium voor acceptatie van nieuwe zelfcontrolesystemen of de heracceptatie van bestaande systemen.

Ook is de aanpak van de NVWA bij de acceptatie van zelfcontrolesystemen weinig transparant te noemen. Er bestaat onduidelijkheid over de vraag welke zelfcontrolesystemen voor acceptatie door de NVWA in aanmerking komen, hoe die procedure verloopt en welke voorwaarden door de NVWA worden gesteld. Voor de

70 Vgl. Zwetsloot e.a. 2011 die stellen dat een competitief voordeel voor goed presterende bedrijven bij een verplicht certificatiesysteem slechts van tijdelijke aard is en daarna omslaat in een nadeel omdat zij minder in staat zijn te laten zien dat ze beter presteren.

71 P. Verbruggen, Gorillas in the Closet? Public and Private Actors in the Enforcement of Transnational Private Regulation, Regulation \& Governance 2013-7, p. 512-532.

72 M. Wright e.a., Assessment and Comparison of Third Party Assurance Schemes in the Food Sector: Towards a Common Framework, 2013, Final Report for the Food Standards Agency, Project Code FS245006 <www.foodbase.org.uk/results.php?f_category_id=\&f_report_id=835> (15 december 2013, p. 46). 
acceptatie van BDW en RiskPlaza bestonden vooraf geen vastomlijnde criteria en ook thans zijn die niet duidelijk vastgesteld en openbaar. Tussen de NVWA en BDW is geen convenant van kracht dat de afspraken vastlegt, terwijl het convenant met het Productschap Akkerbouw over RiskPlaza slechts een deel van de criteria omschrijft. Dit zorgt voor verwarring en onduidelijkheid bij de zelfcontrolesystemen en vermoedelijk ook bij die organisaties die voor acceptatie in aanmerking willen komen.

Openheid van zaken en duidelijkheid omtrent de voorwaarden voor acceptatie spelen een belangrijke rol bij het scheppen van wederzijds vertrouwen. Het NVWA-beleid wordt thans vooral gekenmerkt door ad-hocbeslissingen. Hoewel dit te verklaren valt door de pragmatische insteek die de NVWA heeft gevolgd (in de woorden van een medewerker 'learning by doing'), zou een zekere mate van formalisering en uniformering van de huidige aanpak de transparantie van metatoezicht ten goede komen.

\section{Conclusie}

De analyse van de zelfcontrolesystemen van BDW en RiskPlaza leert dat de NVWA zeker niet over één nacht ijs is gegaan bij de acceptatie van deze systemen. Haar aanpak kenmerkt zich door pragmatisme en het is gelukt haar metatoezicht met enkele fundamentele waarborgen te omkleden. Het verschil in aanpak van metatoezicht bij de systemen van BDW en RiskPlaza is vooral gelegen in de uiteenlopende gevolgen van acceptatie van BDW en RiskPlaza voor het toezicht van de NVWA. BDW moet aan een uitgebreider (strenger) eisenpakket voldoen dan RiskPlaza omdat een positieve BDW-beoordeling vrijstellingen van NVWAinspecties bewerkstelligt. In het geval van RiskPlaza leidt een positieve audit slechts tot gedeeltelijke vervanging van NVWA-controles. Ook speelt mee dat de NVWA in het geval van RiskPlaza betrokken was bij de ontwikkeling van het systeem en thans nog een formele rol heeft bij de vaststelling van de te toetsen voedselveiligheidsnormen. Voor de overige omstandigheid waarvan werd verondersteld dat deze invloed op de vormgeving van metatoezicht zou hebben, te weten het verschil in betrokken commerciële belangen bij BDW en RiskPlaza, is geen aanwijzing gevonden. Deze uitkomst laat zich verklaren doordat bij RiskPlaza, hoewel niet-commercieel van aard, toch commerciële certificatie-instellingen betrokken zijn die de controles uitvoeren.

De analyse laat ook een aantal zwakke punten aan het metatoezicht van de NVWA zien. In de eerste plaats komen die voort uit het gegeven dat er met private toezichthouders wordt samengewerkt die een andere rationaliteit voorstaan, namelijk zorgen voor een financieel gezond bedrijf. Bijgevolg zouden de private controles minder strikt kunnen zijn dan de publieke. De NVWA probeert dit te ondervangen door $100 \%$ controle en een hoger niveau van naleving te verlangen. In hoeverre zelfcontrolesystemen dit waarmaken, moet op termijn nog blijken. Een potentiële valkuil van het huidige systeem van metatoezicht is dat de NVWA onvoldoende capaciteit heeft om de bedrijven te controleren die niet deelnemen aan de geaccepteerde zelfcontrolesystemen. Deze bedrijven genieten daarom een 
kostenvoordeel ten opzichte van de wel deelnemende bedrijven, waardoor het zelfcontrolesysteem een weinig aantrekkelijk initiatief wordt. Voorts zou de NVWA er goed aan doen een verplichting op te nemen voor zelfcontrolesystemen om melding te maken van ernstige inbreuken op voedselveiligheidsregels of acuut gevaar voor de volksgezondheid, alsmede haar huidige aanpak te formaliseren en te uniformeren om duidelijkheid rondom acceptatie te creëren. Dit zijn lessen die ook voor andere publieke toezichthouders kunnen gelden wanneer zij de strategie van metatoezicht zouden toepassen. ${ }^{73}$

Nochtans moet de echte werking van deze vorm van metatoezicht door de NVWA nog blijken. De controles van de systemen door de NVWA heeft zich tot nu toe slechts gericht op de acceptatie. Het is nog nauwelijks duidelijk hoe de NVWA na acceptatie zicht blijft houden op de prestaties van de zelfcontrolesystemen. Momenteel wordt al wel binnen de NVWA nagedacht over de vraag in hoeverre de toezichtactiviteiten van de NVWA kunnen worden afgestemd met GFSI gebenchmarkte certificatieschema's. ${ }^{74}$ Dit doet de vraag rijzen hoe de NVWA ten aanzien van deze initiatieven, die grensoverschrijdend opereren, voldoende zicht kan houden op de kwaliteit en resultaten van de private controles. Bij het zich richten op deze internationale schema's kan de NVWA voortbouwen op haar ervaringen met de acceptatie van de nationaal georiënteerde zelfcontrolesystemen om uiteindelijk een heldere en eenduidige methodiek van metatoezicht te ontwikkelen.

Ten slotte werpt de vraag zich op hoe het metatoezicht van de NVWA op private zelfcontrolesystemen zich verhoudt tot de kritiek die recent is geuit op het functioneren van de NVWA. In november 2013 publiceerde de Onderzoeksraad voor Veiligheid een rapport waarin de wijze van crisisbeheersing en -communicatie van de NVWA tijdens de uitbraak van salmonella in gerookte zalm in het najaar van 2012 als onvoldoende werd beoordeeld. ${ }^{75}$ Het visverwerkingsbedrijf waarvan de zalm afkomstig bleek, werd jaarlijks geaudit overeenkomstig de private certificatiestandaarden van IFS, BRC en een Amerikaanse retailer. De Onderzoeksraad constateert dat het bedrijf voldeed aan de geldende certificatie-eisen; zowel het privaat als het publiek toezicht is echter niet gericht op het onderkennen van nieuwe en onverwachte gevaren en risico's. Binnenkort verschijnt ook een kritisch onderzoek opgesteld in opdracht van de Stichting Maatschappij en Veiligheid over de wijze waarop de NVWA thans haar toezichttaak uitvoert. ${ }^{76}$ De Stichting Maatschappij en Veiligheid wijst op negatieve consequenties van

73 De rijksinspecties werken binnen de Inspectieraad gezamenlijk aan de ontwikkeling en implementatie van horizontaal toezicht en systeemtoezicht <www.inspectieloket.nl/Images/VT_werk programma_2012_2013_2012-juni_website_tcm296-332126.pdf> (30 augustus 2013).

74 GFSI (Global Food Safety Initiative) is een initiatief van internationale supermarktketens dat internationale voedselveiligheidsstandaarden en -certificatieschema's beoordeelt ('benchmarkt'). Thans loopt er een pilotproject bij de NVWA om de betrouwbaarheid van GFSI gebenchmarkte certificatieschema's te inventariseren. Zie: Beuger 2012, p. 21.

75 Onderzoeksraad voor Veiligheid, Salmonella in gerookte zalm, 2013, <www.onderzoeksraad.nl/ uploads/phase-docs/450/4e4564b46952rapport-salmonella-nl-web.pdf> (6 februari 2014).

76 Stichting Maatschappij en Veiligheid, Voedselveiligheid - Balans van verantwoordelijkheden, 2013, <www.maatschappijenveiligheid.nl/balans-van-verantwoordelijkheden-door-prof-mrpieter-van-vollenhoven-voorzitter-stichting-maatschappij-en-veiligheid/> (6 februari 2014). 
zelfregulering en bepleit dat de eigen verantwoordelijkheid van bedrijven voor de veiligheid van hun producten wettelijk wordt vastgelegd en dat de overheid toeziet op naleving. De Stichting wijst erop dat economische belangen vaak op gespannen voet staan met veiligheid. De Consumentenbond is eveneens van oordeel dat er sprake is van te veel vertrouwen in zelfcontrole door de sector en bepleit een verplichte inkoopcontrole en de plicht om onvolkomenheden die daarbij aan het licht komen bij de NVWA te melden. ${ }^{77}$

Naar aanleiding van diverse incidenten (fraude met paardenvlees, met salmonella besmette zalm, toezicht slachterijen) is geconstateerd dat de NVWA haar verantwoordelijkheid voor toezicht en handhaving onvoldoende kan waarmaken. Dit heeft in december 2013 geleid tot een 'Plan van aanpak'78 waarin onder andere een fundamentele herbezinning wordt aangekondigd op de inrichting van het systeem van keuring en toezicht. Een van de aandachtspunten hierbij is de positie en rol van private kwaliteitssystemen en privaatrechtelijke keuringsdiensten die taken uitvoeren waarop het Rijk vervolgens toezicht houdt. Dit systeem staat onder druk in het fytosanitaire en veterinaire domein vanwege Europese en internationale verdragen en bij de export van zuivelproducten vanwege kritiek van derde landen (zoals Rusland) op controles door het Centraal Orgaan Kwaliteitsaangelegenheden in de Zuivel (COKZ). Zowel het 'Plan van aanpak' als de genoemde kritische rapporten en standpunten duiden op een kentering in het denken over zelfregulering en controles door private organisaties. Het is onduidelijk welke consequentie deze herbezinning zal hebben voor de acceptatie van zelfcontrolesystemen door de NVWA.

Dat de NVWA de laatste maanden sterk onder druk staat, zou eveneens invloed kunnen hebben op de toekomstige ontwikkeling van het gebruik van private zelfcontrolesystemen voor de invulling van de publieke toezichttaak. Men kan zich immers eenvoudig de krantenkoppen en Kamervragen voorstellen op het moment dat zich een incident voordoet in een bedrijf waarbij door middel van een geaccepteerd privaat zelfcontrolesysteem toezicht werd gehouden op voedselveiligheid. De NVWA zal dan veel kritiek te verduren krijgen en zich moeten verantwoorden. Het komt er dan op aan dat de NVWA zowel aan het publiek als aan de politiek kan uitleggen dat het verantwoord was om het feitelijk toezicht over te laten aan commerciële partijen en zelf geen direct toezicht meer te houden.

77 Brief van de Consumentenbond aan staatssecretaris Dijksma over 'voedselvertrouwen en NVWA' van 4 februari 2014, <www.consumentenbond.nl/nieuws/afbeeldingen/Staatssecretaris_ Dijksma_voedselvertrouwen_en_nvwa_website.pdf> (14 februari 2014).

78 Plan van aanpak NVWA, bijlage bij brief van de minister van Economische Zaken aan de Tweede Kamer van 19 december 2013, <www.rijksoverheid.nl/documenten-en-publicaties/rapporten/ 2013/12/19/bijlage-plan-van-aanpak-nvwa.html> (14 februari 2014). 